\title{
Vaccines from Monoclonal Anti-Idiotypic Antibody: Poliovirus Infection as a Model
}

\author{
F.G.C.M. UytdeHaAG and A.D.M.E. Osterhaus
}

1 Introduction 31

2 Generation of Antipoliovirus Type II Neutralizing Antibody by Monoclonal Ab2 33

3 Discussion 37

References 40

\section{Introduction}

Manipulation of the immune system by "foreign" substances, i.e., the induction of protective immune response against certain pathogens by vaccination has proven to be of great practical value in contributing to the control of infectious diseases in man and animals. In the case of smallpox, it has even led to the eradication of the disease. However, for a number of infectious diseases there are still major problems in the production of effective vaccines. This is partly due to the fact that antigens cannot be generated in sufficient amounts or in the proper immunogenic form. Among the different approaches to overcoming these problems (reviewed by ARNON et al. 1983 and NORRBY 1983) the use of the elements of the immune system itself, i.e., anti-idiotypic antibodies has recently attracted great attention (see e.g. NisONOFF and LAMOYI 1981 and ZOLER 1984). In light of present idiotype (Id) research, it must be considered possible to administer anti-Id antibody (Ab2) exogenously to replace antigen for the induction of specific immune response (see for review, RAJEWSKI and TAKEMORI 1983 and SACKS and SHER 1983).

Several groups, using biologically important models of microbial infection, have now shown that the administration of polyclonal xenogeneic or allogeneic Ab2 to animals can either prime for a protective antibody response upon subsequent antigen exposure, or can induce neutralizing antibodies in animals in absence of antigen (SACKS et al. 1981; 1983; KENNEDY et al. 1982, $1983 \mathrm{a}$, b; KenNedy and Dreesman 1983, 1984; Reagan et al. 1983). In principle, apart from obvious theoretical implications, polyclonal xenogeneic or allogeneic Ab2 preparations for the development of a vaccine have several major practical disadvantages. (a) It would be very difficult to establish production of polyclonal

The National Institute of Public Health and Environmental Hygiene, P.O. Box 1, NL-3720 BA Bilthoven 
Ab2 preparations of high consistency and identity. (b) A polyclonal Ab2 preparation would contain a heterogeneous population of anti-Id specificities where only a small fraction induces Id-bearing molecules which will also bind antigen. The rapidly progressing developments in hybridoma technology (for review, see e.g., Osterhaus and UytdeHaAg 1985 have raised the possibility for largescale production of homogeneous Id-bearing and anti-Id antibody preparations of high consistency and purity. A monoclonal Ab2 detecting an interspecies crossreactive idiotope (CRI) associated with the immune response against, for example, a neutralization domain of a viral epitope or possessing an "internal image" of such an epitope would represent the ideal anti-Id vaccine. The induction of antiviral T-cell mediated immunity by monoclonal Ab2 and monoclonal anti-T cell idiotope antibodies has also been reported (NOSEWORTHY et al. 1983; Kauffman et al. 1983; Sharpe et al. 1984; Ertl and Finberg 1984).

In the present paper, we will consider the potential of monoclonal Ab2 for the induction of protective immune response against poliovirus infection. Endemic poliomyelitis has been exterminated from several industrialized countries with either oral attenuated poliovirus or inactivated poliovirus vaccines. However, also in these countries poliomyelitis remains a permanent threat as was recently shown by an outbreak of the disease caused by poliovirus type III in Finland (AnONymous (1985). In the developing world, this disease is still a major problem, and there is urgent need for an effective vaccine that can be produced at low cost for worldwide distribution, perhaps even with the final goal of complete eradication of the disease. For this purpose, a vaccine not containing live virus would be the most suitable candidate. The presently available inactivated polio vaccines will not fill this gap since they are produced in primary or subcultivated monkey-kidney cells, which cannot be produced in sufficient amounts at sufficiently low cost. Among the recent developments in this field is the evaluation of similar vaccines produced in continuous monkeykidney cell lines (Beale 1980; Von Seefried and Chun 1980; Horodniceanu et al. 1980). Although this approach will certainly expand the potential of inactivated polio vaccines on a quantitative basis, the discussion about the safety of these vaccines with regard to the tumorogenous potential of the cells used for production has not been fully evaluated (PROCEEDINGS OF THE WORKSHOP ON ABNORMAL CELLS, NEW PRODUCTS AND RISKS 1984). At least, this will lead to the requirement of extra purification steps, to demonstrate the absence of cellular nucleic acids. Developments in the field of the generation of a recombinant DNA or even a synthetic vaccine against poliovirus have been very encouraging, although especially the importance of conformational antigenic determinants may seriously hamper this approach (EMINI et al. 1983; EvANs et al. 1983; MinoR et al. 1983; B. Wieringa, personal communication).

In a first approach to test the feasibility of a monoclonal Ab2 as an antiviral vaccine we choose the poliovirus system mainly because of the assumed limited number of neutralization-inducing epitopes on polioviruses (FERGUSSON et al. 1984; Evans et al. 1983). This would enable us in principle to use a limited panel of monoclonal Ab2 as a vaccine. Furthermore, humoral immunity is probably the major component of the protective immune response against infection with poliovirus. The third and perhaps most practical reason to choose 
this model is that a protective immune response in mice may be elicited by one single inoculation of one monoclonal neutralizing antipoliovirus antibody (Osterhaus, personal communication). Finally, a recently developed in vitro system for the induction and measurement of a poliovirus-specific neutralizing antibody response using human peripheral blood lymphocytes (UYTDEHAAG et al. 1985a) will offer the possibility to study at least some aspects of the Ab2-induced humoral immune response in man.

\section{Generation of Antipoliovirus Type II Neutralizing Antibody by Monoclonal Ab2}

Three monoclonal Ab1 were selected from a panel of monoclonal antibodies with specificity for neutralization-inducing epitopes of the $\mathrm{MEF}_{1}$ strain of poliovirus type II (Osterhaus et al. $1981 \mathrm{a}, \mathrm{b}, 1983$ ). Selection was based on the broad reactivities of the monoclonal Ab1 against various poliovirus type II strains, as tested in a microvirus neutralization test (Table 1). Considering these observations, as well as the facts that the three monoclonal Ab1 derived from two different fusions and the binding of one monoclonal Ab1, 1-10C9E8, to the virus could be inhibited by the other two (Fig. 1), it was deduced that these three Ab1 define a major (and probably the same) neutralization-inducing epitope on poliovirus type II strain $\mathrm{MEF}_{1}$.

Ab1 1-10C9E8 ( $\operatorname{IgG} 2 \mathrm{a} \kappa)$ purified from ascitic fluid using protein A-sepharose affinity chromatography, was subsequently used to raise syngeneic mono-

Table 1. Inter- and intratypic micro-VN titers of antipoliovirus monoclonl antibodies (Ab1)

\begin{tabular}{|c|c|c|c|}
\hline \multirow[t]{2}{*}{ Polioviruses } & \multicolumn{3}{|l|}{ Monoclonal antibodies } \\
\hline & 81/21 MEF 1-10C9E8 & 81/21 MEF 4-15D4E8 & $81 / 10 \mathrm{MEF} 11 \mathrm{E} 7$ \\
\hline \multicolumn{4}{|l|}{ Type II } \\
\hline $\begin{array}{l}\text { MEF }_{1} \\
\text { Sabin } \\
\text { SL } 188 / 4 / 3 \\
\text { NSL } 81-4789 \\
\text { NSL } 77-728 \\
\text { NSL } 2188 \\
\text { NSL } 77-686 \\
\text { NSL } 64-80\end{array}$ & $\begin{array}{r}781.250 \\
156.250 \\
3.906 .250 \\
781.250 \\
781.250 \\
781.250 \\
3.906 .250 \\
3.906 .250\end{array}$ & $\begin{array}{r}781.250 \\
156.250 \\
3.906 .250 \\
\geq 3.906 .250 \\
\geq 3.906 .250 \\
\geq 3.906 .250 \\
\geq 3.906 .250 \\
3.906 .250\end{array}$ & $\begin{array}{r}781.250 \\
6.250 \\
156.250 \\
156.250 \\
156.250 \\
156.250 \\
156.250 \\
156.250\end{array}$ \\
\hline \multicolumn{4}{|l|}{ Type I } \\
\hline $\begin{array}{l}\text { Mahoney } \\
\text { Sabin }\end{array}$ & $\begin{array}{l}<10 \\
<10\end{array}$ & $\begin{array}{l}<10 \\
<10\end{array}$ & $\begin{array}{l}<10 \\
<10\end{array}$ \\
\hline \multicolumn{4}{|l|}{ Type III } \\
\hline $\begin{array}{l}\text { Saukett } \\
\text { Sabin }\end{array}$ & $\begin{array}{l}<10 \\
<10\end{array}$ & $\begin{array}{l}<10 \\
<10\end{array}$ & $\begin{array}{l}<10 \\
<10\end{array}$ \\
\hline
\end{tabular}




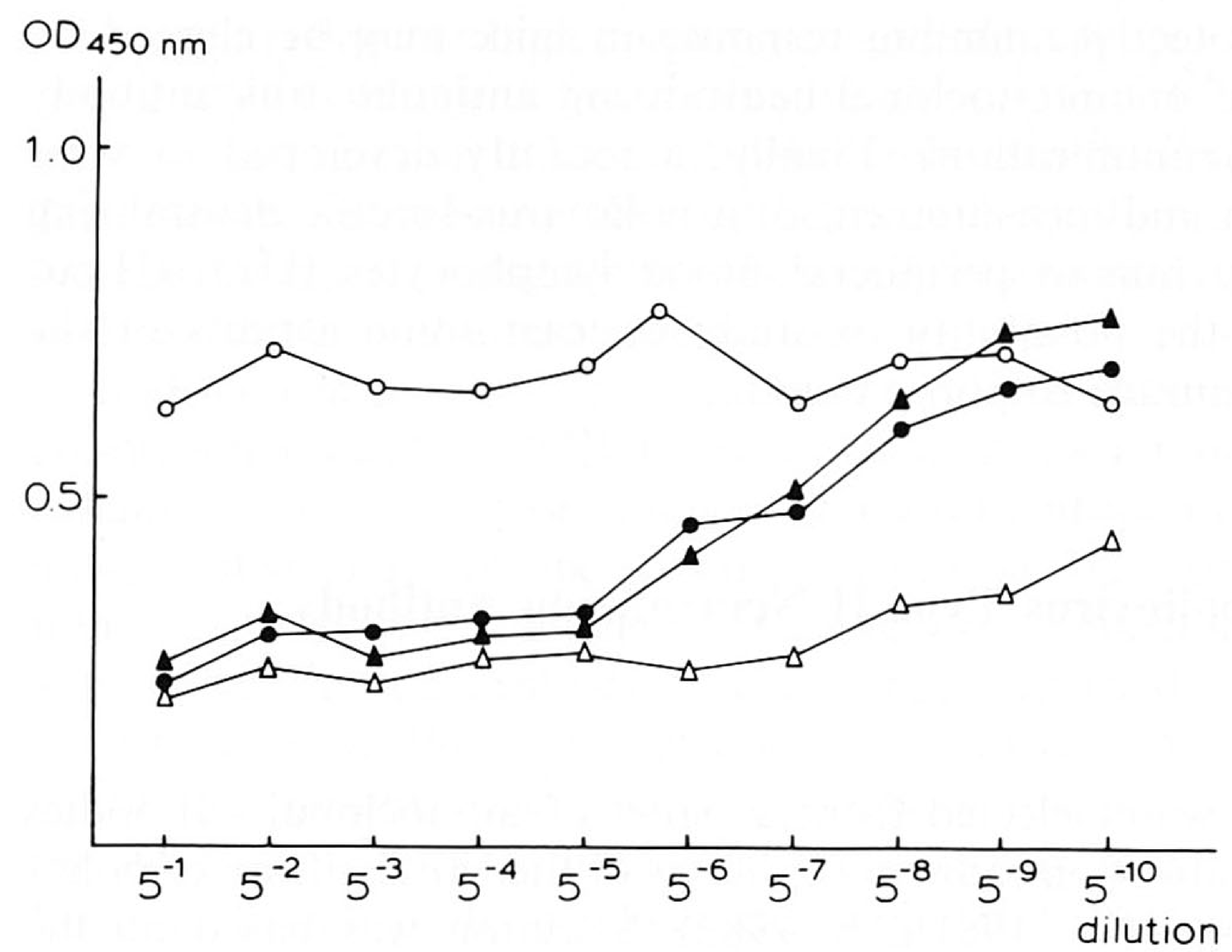

Fig. 1. Inhibition of the binding of peroxidase conjugated Ab1 to 1-10C9E8 to plate-bound poliovirus type II by the homologous and two other heterologous monoclonal antipoliovirus type II antibody preparations. Samples Ab1 1-10C9E8 (৯), Ab1 11E7 (•), Ab1 4-15D4D8 ( $)$ ), and control BALB/c IgG2a $\kappa(0)$ were reacted with plate-bound poliovirus, as described in text. Control BALB/c IgG2a $\kappa$ used as inhibitor resulted in OD $450 \mathrm{~nm}$ values comparable with values obtained with PBS-Tween $0.05 \%$ as inhibitor

clonal Ab2. One out of five clones obtained in three independent fusions showed strong reactivity for Ab1 1-10C9E8 as tested in an idiotope-crosslinking ELISA (see legend to Fig. 2). This Ab2 clone, 2-17C3scc, was recloned using manual isolation of single cells and monoclonal Ab2 2-17C3scc ( IgGl $\kappa$ ) was isolated from the hybridoma supernatant fluid using protein A-sepharose affinity chromatography. Ab2 2-17C3scc showed only binding affinity for Ab1 1-10C9E8 and not for a control BALB/c IgG2a $\kappa$ monoclonal antibody in an Ab1-crosslinking ELISA. In addition, no binding of a control monoclonal IgG1 $\kappa$ to Ab1 1-10C9E8 or to the control IgG2a $\kappa$ was found (Fig. 2A).

The idiotope on Ab1, 1-10C9E8, as defined by Ab2, 2-17C3scc, was found to be closely associated with its paratope. The binding of horseradish peroxidase labeled Ab2 2-17C3scc to Ab1 1-10C9E8 f(ab')2 could completely be inhibited by poliovirus type II, but not poliovirus type I or type III (Fig. 2 B).

A series of competitive inhibition studies were performed to characterize the idiotope defined by Ab2 2-17C3scc. First, either monoclonal neutralizing Ab1 or non neutralizing Ab1 against the different types of poliovirus were tested for inhibition of Ab1 1-10C9E8 idiotope crosslinking by Ab2 2-17C3scc in ELISA. To that end amounts of Ab2 2-17C3scc, at a dilution giving $50 \%$ binding in Ab1 1-10C9E8 crosslinking ELISA, were incubated overnight with equal amounts of serial dilutions of the various monoclonal Ab1. Then, the remaining anti-Ab1 1-10C9E8 activity in Ab2 was determined in the Ab1 1-10C9E8 crosslinking ELISA. A dose-related inhibition in Ab1 1-10C9E8 crosslinking was observed by preincubation of Ab2 2-17C3scc with Ab1 1-10C9E8, and with two other monoclonal antipoliovirus type II monoclonal antibodies, 
A

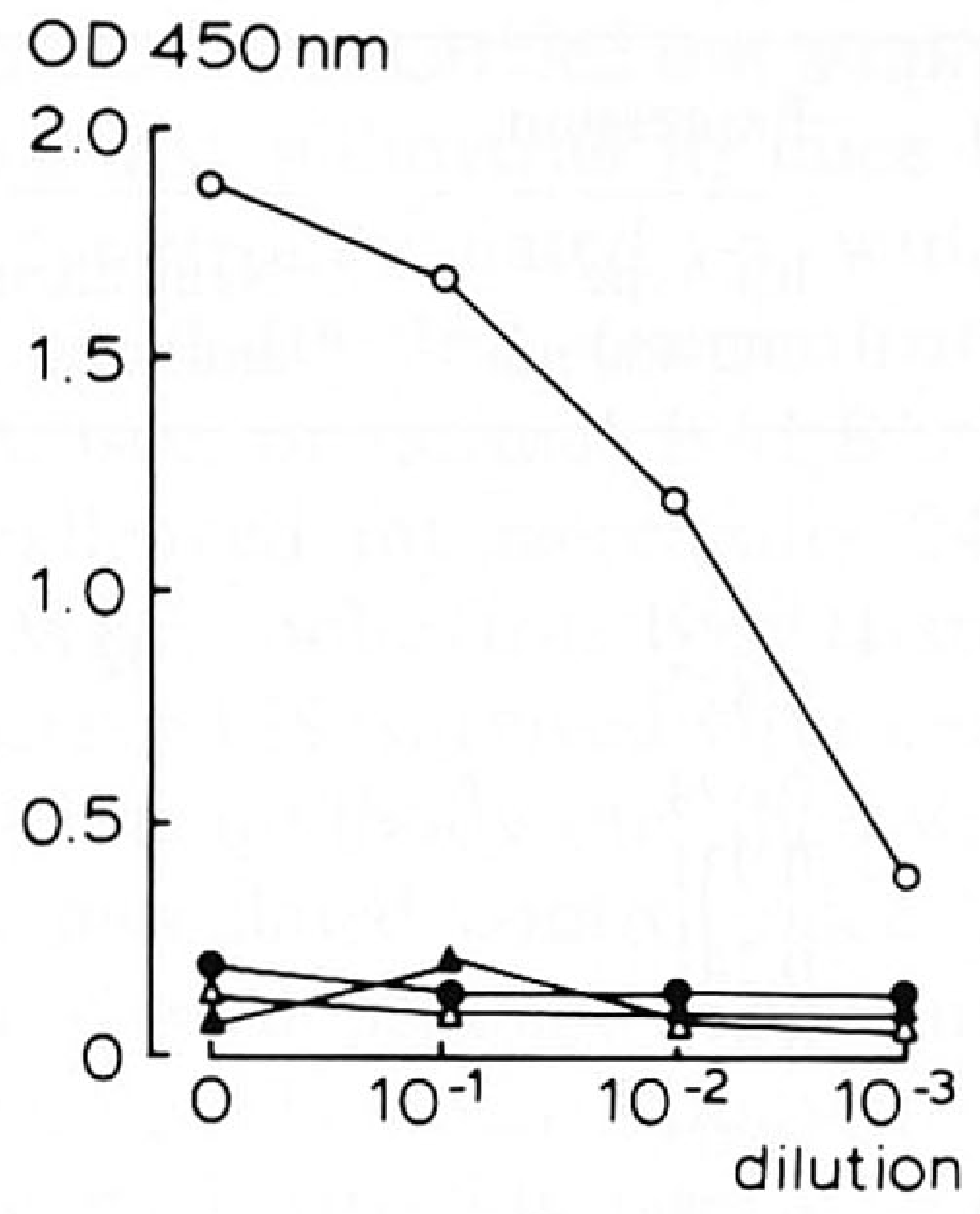

C

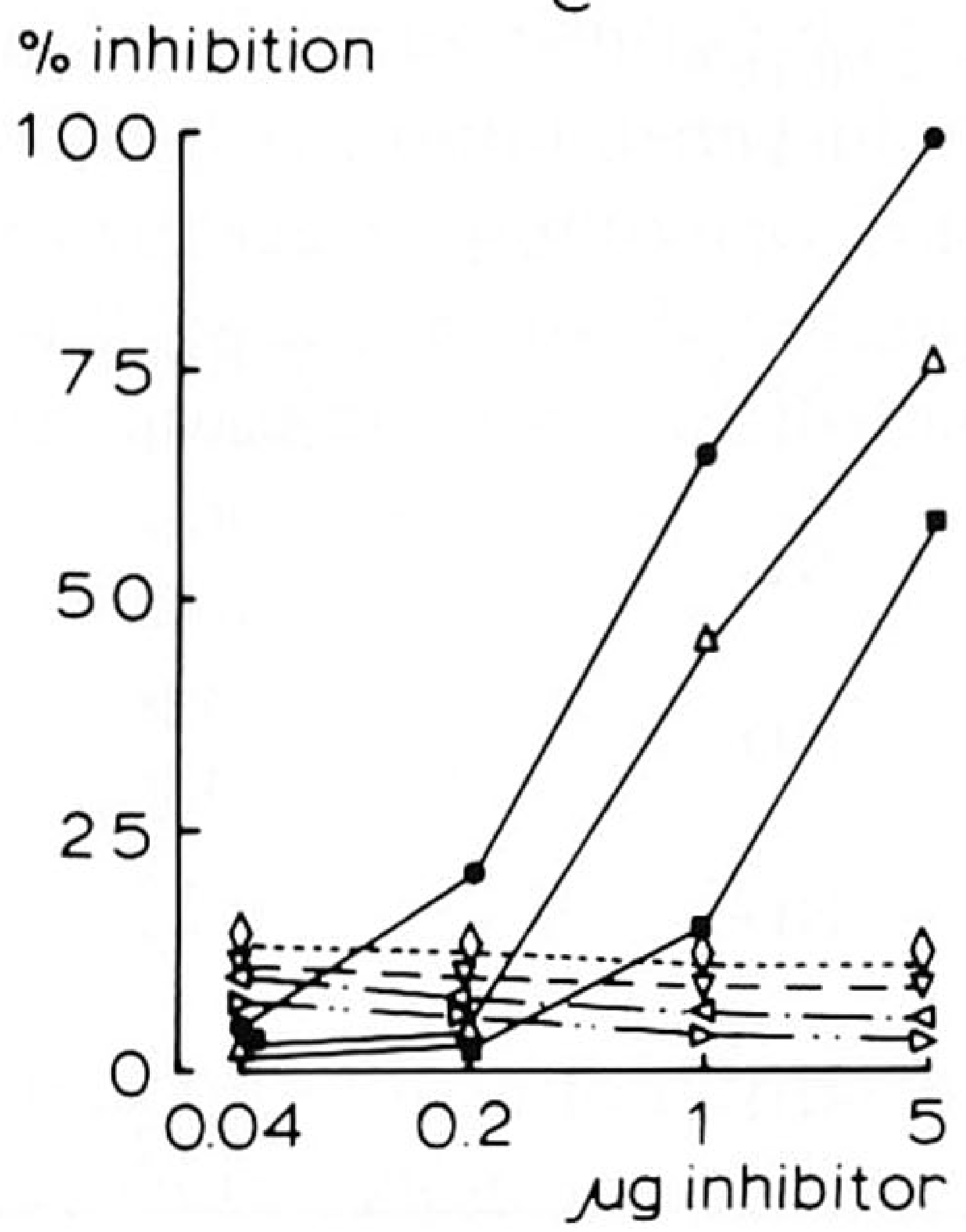

B

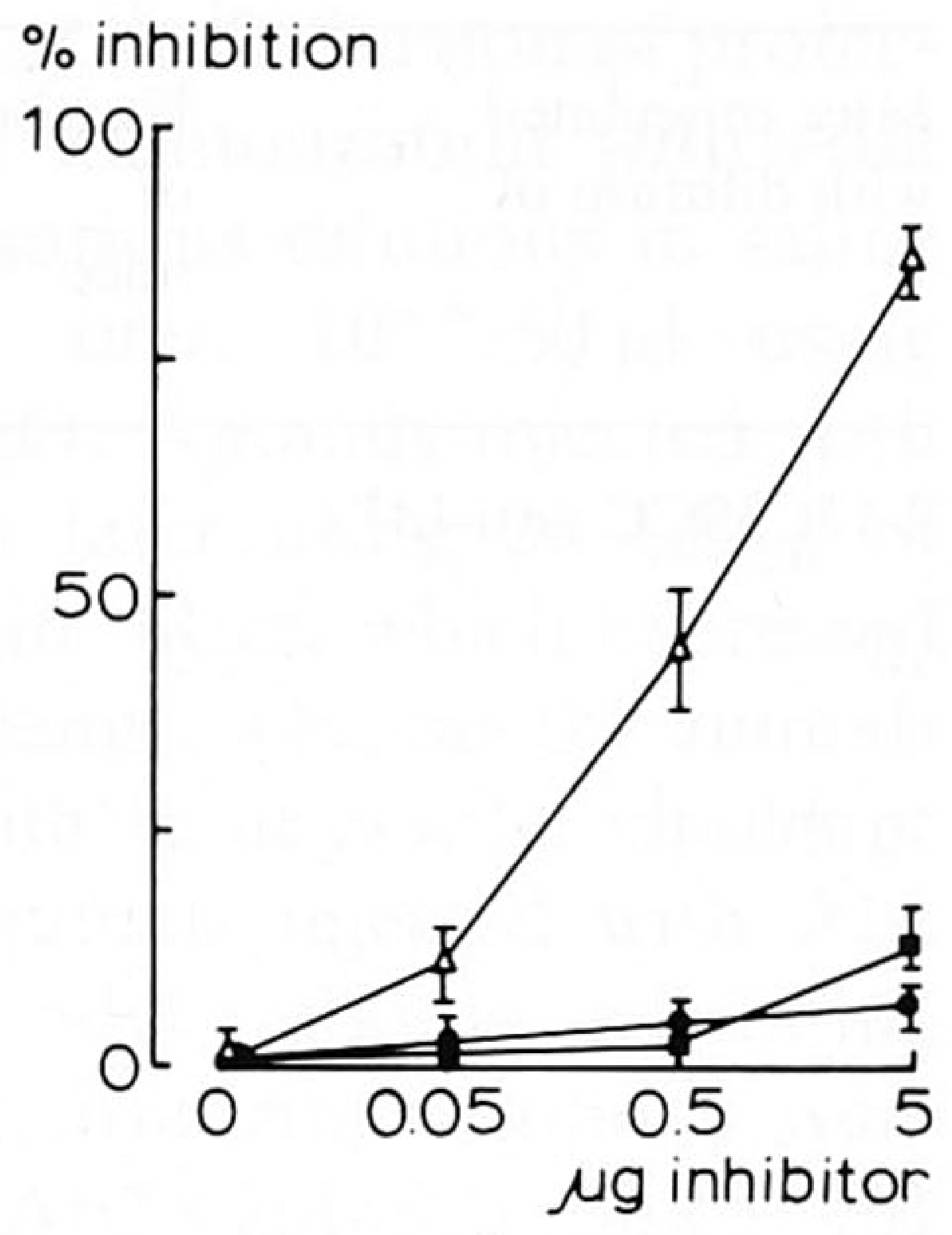

$\%$ inhibition

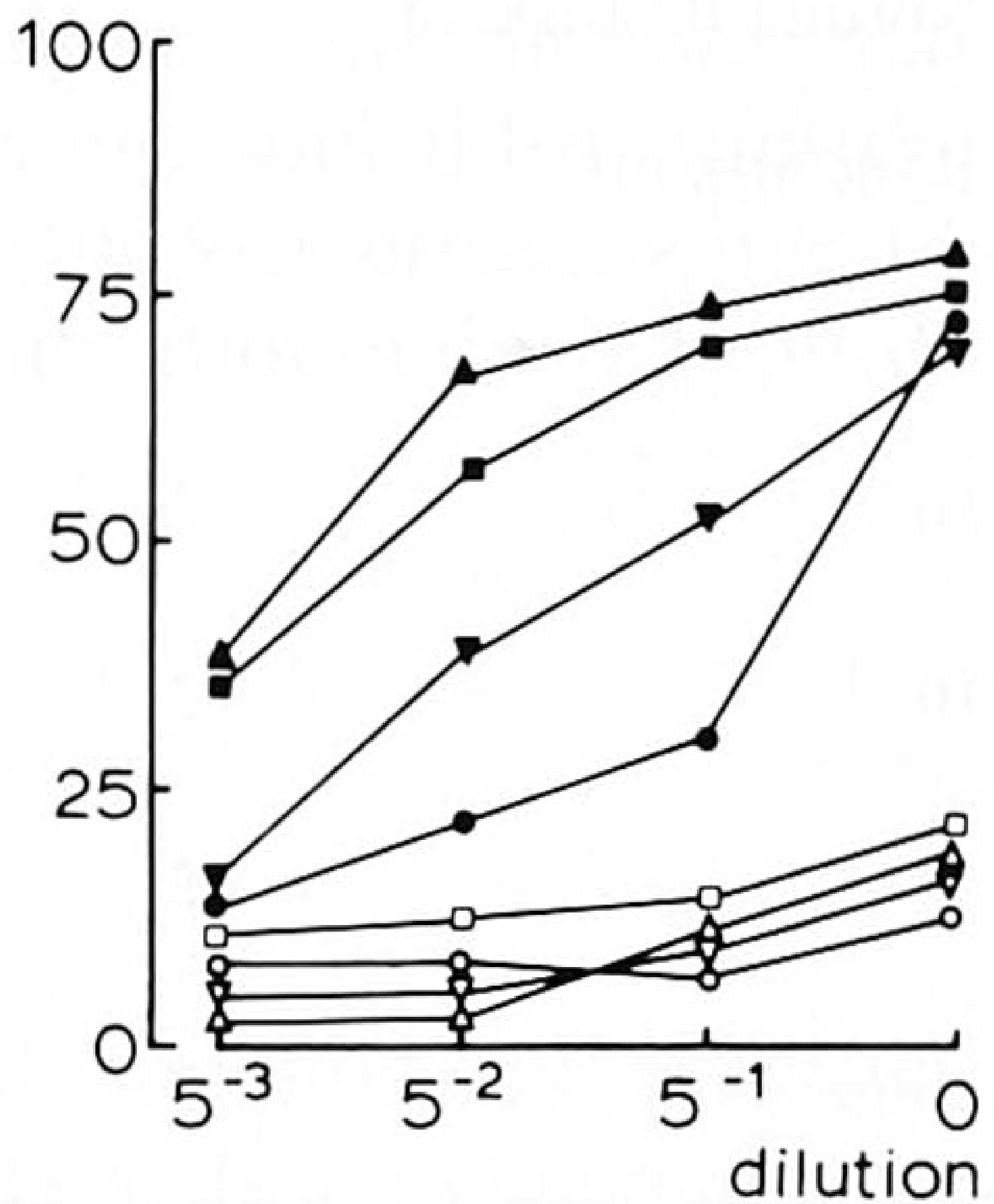

Fig. 2. A Detection of anti-idiotope in idiotope cross-linking ELISA. $F\left(a b^{\prime}\right) 2$ protein A purified supernatant fluids of anti-idiotope producing hybridoma cell line 2-17C3SCC (o), or control BALB/c IgG2a $\kappa(\Delta)$ were incubated on ELISA plates coated with either idiotope Ab1 1-10C9E8 (open symbols) or control BALB/c IgG2a $\kappa$ (closed symbols). Plates were further developed with the horseradish peroxidase labeled idiotope Ab1 1-10C9E8. Similar results were obtained in seven separate experiments. b Detection of paratope-related idiotope. Inhibition of binding of horseradish peroxidase labeled anti-idiotope 2-17C3SCC to plate-bound idiotope 1-10C9E8 by poliovirus type I. (•), type II $(\Delta)$, and type III ( $\bullet$ ). Data are presented as the mean \pm SE of triplicate determination. $\mathbf{c}$ Detection of crossreactive idiotope. Inhibition of idiotope cross linking ELISA by incubation of anti-idiotope 2-17C3SCC with neutralizing antipoliovirus type II monoclonal antibodies; 1-10C9E8 (•), 11E7 $(\triangle), 4-15 \mathrm{D} 4 \mathrm{D} 8(-)$ or other monoclonal antibodies; nonneutralizing antipoliovirus type II $(\diamond)$, neutralizing antipoliovirus type I $(\triangleleft)$, neutralizing antipoliovirus type III $(\nabla)$, and control BALB/c IgG2a $\kappa(\triangleright)$. Similar results were obtained in three separate experiments. D Detection of interspecies crossreactive idiotopes. Inhibition of idiotope crosslinking ELISA by incubation of anti-idiotope 2-17C3 with antipoliovirus type II hyperimmune sera (closed symbols) of rats (\$), guinea pigs ( $\mathbf{\bullet})$, mice $(\bullet)$, and humans $(\mathbf{v})$, or their respective preimmune sera (open symbols). One pannel of representative data is given from experiments in which sera were tested from 6 rats, 2 guinea pigs, 12 mice, and 12 human individuals

Ab1 4-15D4E8 and Ab1 11E7, but not with non-neutralizing antipoliovirus type II or neutralizing antipoliovirus type I and III monoclonal antibodies (Fig. 2C). Since Ab1 1-10C9E8 and Ab1 4-15D4E8 were obtained from a hybridization other than Ab1 11E7, these results strongly indicate that the 
Table 2. Anti-Id 2-17C3SCC induces expression of neutralizing 1-10C9E8 related Id

\begin{tabular}{|c|c|c|c|c|}
\hline \multirow{2}{*}{$\begin{array}{l}\text { Mice inoculated } \\
\text { with dilution of }\end{array}$} & \multirow{2}{*}{$\begin{array}{l}\text { Number } \\
\text { of } \\
\text { mice }\end{array}$} & \multicolumn{2}{|l|}{ Expression } & \multirow{2}{*}{$\begin{array}{l}\text { Survival } \\
\text { after } \\
\text { challenge } \\
\text { days }\end{array}$} \\
\hline & & $\begin{array}{l}\text { Idiotype }^{\mathrm{c}} \\
\text { OD } 450 \mathrm{~nm}\end{array}$ & $\begin{array}{l}\text { Neutralizing } \\
\text { antibody }\end{array}$ & \\
\hline \multicolumn{5}{|l|}{ 2-17C3SCC anti-Id ${ }^{b}$} \\
\hline $10^{\circ}$ & 2 & $\begin{array}{l}1.635 \\
0.477\end{array}$ & 32 & $\begin{array}{r}5 \\
10\end{array}$ \\
\hline $10^{-1}$ & 2 & $\begin{array}{l}0.594 \\
0.931\end{array}$ & 32 & $\begin{array}{l}10 \\
11\end{array}$ \\
\hline $10^{-2}$ & 2 & $\begin{array}{l}0.341 \\
0.611\end{array}$ & $<2$ & $\begin{array}{r}9 \\
12\end{array}$ \\
\hline $10^{-3}$ & 2 & $\begin{array}{l}0.209 \\
0.178\end{array}$ & $<2$ & $\begin{array}{l}8 \\
7\end{array}$ \\
\hline Normal BALB/c Ig & 2 & $\begin{array}{l}0.107 \\
0.119\end{array}$ & $<2$ & $\begin{array}{r}9 \\
10\end{array}$ \\
\hline \multicolumn{5}{|l|}{$1-10$ C9E8 $\mathrm{id}^{\mathrm{c}}$} \\
\hline $10^{\circ}$ & 2 & $N^{d}$ & $\begin{array}{l}>4096 \\
>4096\end{array}$ & $>25$ \\
\hline $10^{-1}$ & 2 & ND & $\begin{array}{l}2048 \\
2048\end{array}$ & $>25$ \\
\hline $10^{-2}$ & 2 & ND & $\begin{array}{l}128 \\
128\end{array}$ & $>25$ \\
\hline $10^{-3}$ & 2 & ND & $\begin{array}{l}8 \\
2\end{array}$ & $\begin{array}{l}15 \\
13\end{array}$ \\
\hline None & 2 & ND & $\begin{array}{l}<2 \\
<2\end{array}$ & $\begin{array}{r}14 \\
9\end{array}$ \\
\hline
\end{tabular}

a The idiotope 1-10C9E8 was used as protein $\mathrm{A}$ purified material with a neutralization titer of $10^{4.9} / 50 \mu \mathrm{l}$ using 100 TCID $_{50} .0 .5 \mathrm{ml}$ of the respective dilutions was inoculated in individual mice, $24 \mathrm{~h}$ prior to challenge with $20 \mathrm{LD}_{50}$ of poliovirus type II, strain MEF1

b The anti-Id 2-17C3SCC was a protein-A purified preparation from hybridoma supernatant fluid with a protein content of $5 \mu \mathrm{g} / \mathrm{ml}$. Mice were injected twice with $0.5 \mathrm{ml}$ anti-Id in saline. Animals were challenged on day 6

c Sera of individual mice were assayed for the ability to cross-link plate-bound Ab2, 2-17C3SCC with HRPO labeled Ab2, 2-17C3SCC in ELISA

d ND, not determined

1-10C9E8 is an intrastrain crossreactive idiotope. This conclusion was confirmed by the observation that sera from BALB/c mice hyperimmunized with poliovirus type II also inhibited Ab1 1-10C9E8 idiotope crosslinking by Ab2 2-17C3scc, while preimmune sera of the animals failed to inhibit this reaction. Moreover, antipoliovirus type II hyperimmune sera of rats, guinea pigs, and humans tested in neutralization assays, but not their preimmune sera, inhibited Ab1 1-10C9E8 idiotope crosslinking by Ab2 2-17C3scc (Fig. 2 D).

These results provide evidence for the expression of the 1-10C9E8 idiotope as a major crossreactive idiotope in association with a neutralizing antibody response towards poliovirus type II in different species. 
Because Ab2 2-17C3scc defines (at least operationally) an interspecies crossreactive idiotope, experiments were carried out aiming at the induction of protective immune response against poliovirus in mice by immunization with $\mathrm{Ab} 2$ 2-17C3scc. BALB/c mice were inoculated i.p. with various dilutions in saline of $5 \mu \mathrm{g} / \mathrm{ml}$ purified Ab1 1-10C9E8 (neutralizing titer, $10^{4.9} / 50 \mu \mathrm{l}$ using 100 TCID $_{50}$ ), Ab2 2-17C3scc, or normal BALB/c IgG. Animals injected with Ab1 1-10C9E8 were challenged intracerebrally $24 \mathrm{~h}$ later using $20 \mathrm{LD}_{50}$ of a mouse brain adapted $\mathrm{MEF}_{1}$ poliovirus type II strain. Mice, which expressed neutralizing antibody titers $\geq 128$, survived virus challenge, whereas the animals expressing $<128$ neutralizing antibody titer died within 15 days after challenge as did the nonantibody inoculated control mice. Animals injected with Ab2 2-17C3scc developed a dose-dependent Ab3 antibody response exhibiting 1-10C9E8 idiotope specificity (Table 2). Poliovirus neutralizing antibody were only detected in mice injected with $5 \mu \mathrm{g}$ and $0.5 \mu \mathrm{g} \mathrm{Ab} 2$ (Table 2). Since Ab2 2-17C3 itself contains no poliovirus neutralizing activity and does not appear to act as a polyclonal activator (unpublished observations), and the mice may be assumed never to be exposed to poliovirus antigen, we concluded from this experiment that Ab2 2-17C3scc acts by expanding 1-10C9E8 crossreactive Idbearing B-cell clones with specificity for a major neutralization-inducing epitope of poliovirus type II.

\section{Discussion}

We have demonstrated that immunization of mice with a monoclonal syngeneic Ab2, directed against a neutralizing antipoliovirus type II monoclonal Ab1, without antigen, induces an Ab3 response, at least a part of which consists of a population of antibody that shares two properties with Ab1: (a) the binding of poliovirus type II strain $\mathrm{MEF}_{1}$ and (b) the binding to Ab2.

Since the idea of using elements of the immune system itself, anti-Id antibodies, to induce immune response against infectious agents was formulated by Nisonoff and Lamoyi (NISONOFF and LAmOY 1981), a few years after the primordial concept of the Id cascade by Cazenave (CAZENAVE 1977) and Urbain (URBAIN et al. 1977), the potential for the practical use of anti-Id antibodies as vaccines has generally been regarded with scepticism. Among the theoretical and practical drawbacks considered are (a) the possible generation of antiallotype and/or anti-isotype reactivity, (b) the fact that in some systems only a priming effect can be generated, (c) the chance to generate antibodies of unknown epitope specificity (auto-immune disease?), and (d) the genetic restriction of the induction of immunity in some systems. However, although no final evaluation of these problems can as yet be made, to a certain extent they may be irrelevant, if one aims at the generation of Ab2 which functions by expanding sets of idiotope-positive clones, some of which are of predetermined epitope specificity (priming). Subsequent boostering by the actual epitope will expand only the clones with corresponding epitope specificity, leaving the rest of the sets initially induced by Ab2 unaffected. 
The general strategy for the preparation of an Ab2 vaccine has so far been the generation of Ab2-defining interspecies CRI, which induce Ab3-sharing antigen-binding capacity with Ab1. In the present studies Ab2 2-17C3scc defines not only a paratope-related idiotope on Ab1 1-10C9E8, but also idiotopes on two other poliovirus type II neutralizing monoclonal antibodies. Since screening of hyperimmune sera from several species, including man, revealed a striking association between the Ab2 2-17C3scc binding idiotope and poliovirus type II specific antibody, these results strongly indicate that Ab2 2-17C3scc defines an interspecies CRI that constitutes a major component of the immune response to poliovirus type II. The phenomenon of interspecies CRI has been interpreted as the conservation of genes in the germline through extended periods of evolution (Ju et al. 1978, 1979; Theze and Moreau 1978; Claflin and Davie 1974; SOMmĖ et al. 1984; KenNedy et al. 1983 b and KenNedy and DreESMAN 1984). We also favor this interpretation to explain the expression of the Ab1 1-10C9E8 interspecies CRI observed in the poliovirus system. The recent development in our laboratory of an in vitro system for the induction of a poliovirus typespecific secondary neutralizing antibody response using human peripheral blood lymphocytes, will hopefully allow us to further investigate the regulation of the expression of the 1-10C9E8 idiotope in an antipoliovirus response (UYTDEHAAG et al. 1985a).

An alternative way to explain CRI follows from the consideration that the antibody repertoire of each individual is complete (CoutinHo 1980 and CouTINHO et al. 1983, 1984). This, as stated by JERNE (1984), implies that the immune system not only has the capability to recognize the universe of "foreign" and self-epitopes but is bound, because of the completeness of its repertoire, to recognize its own elements as well. In other words, within one individual idiotopes can be recognized by the combining sites (paratopes) of other molecules and vice versa. Consequently, as has been postulated by (JERNE (1981 and JERNE et al. 1982), anti-idiotopes are capable of mimicking the universe of external and self epitopes, i.e., they may constitute the internal images of epitopes. Internal images of epitopes are most likely to be found in the population of Ab2. They were termed Ab2 by JERNE (1981 and JERNE et al. 1982), and homobodies by LINDEMAN (LINDEMAN 1973). Thus, the reaction of an Ab2 with CRI present in an Ab1 population can be explained on the basis of an internal image on Ab2 carrying an idiotope that resembles the original epitope and consequently reacts with the paratope of $\mathrm{Ab} 1$. The concept of internal image is best illustrated by what is well known as a "classical" example of internal image: Ab2 in the rabbit b6 allotype system (reviewed by CAZENAVE and Roland 1984). Other examples of Ab2 that were found to behave like the antigen (i.e., a hormone), even in a functional way, have been reported (reviewed by STROSBERG 1983). Notwithstanding the supportive data and the fact that in light of JERNE's network theory $(1974,1976)$ the existence of internal images is virtualy inevitable, their existence has been questioned (LINDEMANN 1978) and seriously challenged recently by Roux et al. (1984) and FranSSEN and URBAIN (1985).

While until now the applicability of Ab2 vaccines seemed restricted to internal image Ab2 and/or anti-CRI Ab2, new possibilities have recently emerged from experiments using the immunization cascade idea. 
The primordial idea of Ab2 vaccines is the Id cascade initially demonstrated by CAZenave (1977) and Urbain et al. (1977). They showed that a rabbit immunized with $\mathrm{Ab} 2$ in response to a given antigen can learn to make the same private Id used by another rabbit in response to the same antigen (induction of silent idiotopes). FrancotTE and URBAIN (1984) demonstrated that it is possible to use an Ab2 not displaying the properties of an internal image to induce expression of a rabbit "private" Id in mice. They induced Ab3 in BALB/c mice by injecting rabbit Ab2. These Ab2 were directed against a private Id of rabbit Ab1 anti-TMV specific antibody. In the induced Ab3, they observed the appearence of mouse anti-TMV antibodies sharing the Id of Ab1. This occurred in spite of the fact that the mice had never been exposed to TMV and do not normally express the private rabbit Id. These results obtained in the TMV system, indicate that in principle any Ab2 against a private Id expressed in a particular individual in response to $\mathrm{AgX}$, can induce this $\mathrm{Id}$ in a crossreactive fashion in another individual or species which normally does not express this Id in response to the same $\mathrm{AgX}$. This illustrates that in contrast to what was generally believed initially - the exclusive role of internal image Ab2 and/or Ab2 defining interspecies CRI - also posibilities to expand the available repertoire by activation of silent clones bearing private idiotopes (or intrastrain CRI, see Leo et al. 1984; Meek et al. 1984; Sigal 1982; LuCAS and Henry 1982; Moser et al. 1983) should be seriously considered. All these approaches, however, have in common that they induce an Ab3 population that binds the original epitope and in most cases share idiotopes with Ab1. There are three possible mechanisms whereby $\mathrm{Ab} 2$ induces protective immunity:

1. Ab2 representing internal images of the original epitopes, inducing Ab3 with similar epitope-binding capacity of Ab1, but for the greater part not sharing the CRI of Ab1.

2. Ab2 defines intrastrain, intraspecies, or interspecies CRI, inducing Ab3-sharing CRI and antigen-binding capacity with Ab1.

3. Ab2 defines a private Id, inducing this Id in Ab3 response in a recurrent fashion (CRI) either intrastrain, intraspecies, or interspecies.

For practical reasons it is obvious that future Ab2 vaccines should be composed of monoclonal antibody reagents. The potential of using such monoclonal $\mathrm{Ab} 2$ to induce poliovirus neutralizing antibody has been demonstrated in the present paper. This is the first report on the use of monoclonal Ab2 to be used for vaccine purposes. A similar approach has recently been indicated for the reovirus system by SHARPE et al. (1984). One should, however, bear in mind that such vaccines, because of their unique anti-idiotope specificity will induce antibody of unique epitope specificity. This bears the intrinsic danger of in vivo induction of variant viruses resistant to the immune response on the basis of mutant selection. Therefore, panels of monoclonal Ab2, produced against poly- or monoclonal Ab1, defining different epitopes, should be used. Although the routine production of monoclonal antibodies is still restricted to a small number of animal systems (mouse, rat, and man), this is not likely to constitute a major disadvantage in light of the results of Urbain's group (mentioned above). In addition to this approach, also the direct immortalization of Ab2 producing 
B-cell clones after in vivo or in vitro immunization with antigen may be considered.

As is also the case for recombinant DNA and synthetic vaccines, we are confronted with the question of how to present the immunogenic moiety to the immune system. At present it is not known how or whether these structures require a specific way of presentation, although it was shown that a multimeric form of presentation in combination with class I and II antigens was more efficient (KAUFMANN et al. 1983).

The fact that the mice exhibiting virus-neutralizing (VN) antibody activity after inoculation with Ab2 2-17C3 were not protected against intracerebral challenge may be explained by the presence of only relatively low VN titers, which were obviously too low for effective protection. This was indicated by the protection experiment with Ab1 1-10C9E8, where an effective titer of $\geq 128$ was shown to be necessary. It should be noted that the immunization method of these mice has not been optimized with regard to schedule, dose, and, perhaps more important, "antigenic" presentation. As has been shown to be the case with virus subunit vaccines, where monomeric forms of, for example, spike proteins of enveloped viruses were less immunogenic or even immunosuppressive in comparison with multimeric forms like micelles, virosomes, and, most recently, iscoms (MOREIN et al. 1984 and Osterhaus et al. 1985), it should be considered that also the presentation of Ab2 molecules or their idiotopes to the immune system in multimeric form might be more efficient. This was also independently suggested by the work of KENNEDY and DREESMAN (1984) in the HBV system and by the work of SHARPE et al. (1984) in the reovirus system. Experiments are presently being carried out in our laboratory in which multimeric forms, including iscom-like preparations of $\mathrm{Ab} 2$ 2-17C3, prepared according to a new method developed by Karin LOVGren and Bror MoreIn from the University of Uppsala (personal communication) are compared for their capacity to induce antipoliovirus neutralizing antibody and protection with noncomplexed soluble Ab2 2-17C3, as used in previous experiments.

Given the idea of JERNE (1984) that the immune system is "a hall of mirrors", i.e., self, anti-self, and subsequently anti-anti-self which reflects the outside antigenic universe, an immune response may be considered the reflection of events following a disturbance of the delicate dynamic balance of these components, by external or internal stimuli, that has to be compensated for by changing the complementary elements to a new state of equilibrium. In order to protect against e.g. a viral infection should one not feel more comfortable to have the immune system disturbed by a well-defined battery of its own elements, rather than by ill-defined conventional vaccines? However, for the near future we may not have a better choice than monoclonal mouse Ab2.

Acknowledgements. The authors are grateful to J. Urbain and J.-D. Franssen for stimulating discussions, and wish to acknowledge C. Kruyssen and T. de Haan for handling the manuscript.

\section{References}

Anonymous (1985) Outbreak of poliomyelitis in Finland. Commun Dis Reports 85/06:312 Arnon R, Shapira M, Jacob CO (1983) Synthetic Vaccines. J Immunol Methods 61:261 Beale AJ (1980) Cell substrate for killed poliovaccine production. Dev Biol Stand 47:19 
Cazenave PA (1977) Idiotypic-anti-idiotypic regulation of antibody synthesis in rabbits. Proc Natl Acad Sci USA 74:5122

Cazenave PA, Roland J (1984) Internal images of rabbit immunoglobulin allotopes. Immunol Rev $79: 139$

Claflin JL, Davie JM (1974) Clonal nature of the immune response to phosphoryl choline IV. Idiotypic uniformity of binding site-associated antigenic determinants among mouse anti-phosphoryl choline antibodies. J Exp Med 140:673

Coutinho A (1980) The self non-self discrimination and the nature and acquisition of the antibody repertoire. Ann Immunol (Paris) 131D:235

Coutinho A, Forni L, Holmberg D, Ivars F (1983) Is the network theory tautologic? In: Moller G, Möller E (eds) Genetics of the immune response. Nobel sympsosium 55. Plenum, New York

Coutinho A, Forni L, Holmberg D, Ivars F, Vaz N (1984) From an antigen-centered, clonal perspective of immune responses to an organism-centered, network perspective of autonomous activity in a self-referential immune system. Immunol Rev 79:151

Emini EA, Jameson BA, Lewis AJ, Larsen GR, Wimmer E (1982) Poliovirus neutralization epitopes: analysis and localization with monoclonal antibodies. J Virol 43:997

Ertl HCJ, Finberg RW (1984) Sendai virus-specific T-cell clones: induction of cytolytic T cells by an anti-idiotypic antibody directed against a helper T-cell clone. Proc Natl Acad Sci USA $81: 2850$

Evans DM, Minor PD, Schild GS, Almond JW (1983) Critical role of an eight amino acid sequence of VP1 in neutralization of poliovirus type III. Nature 304:459

Fergusson M, Minor PD, Margrath DI, Qui Yi-Hua, Spitz M, Schild GC (1984) Neutralizing epitopes on poliovirus type 3 particles: an analysis using monoclonal antibodies. J Gen Virol 65:197

Francotte M, Urbain J (1984) Induction of anti-tobacco mosaic virus antibodies in mice by rabbit antiidiotypic antibodies. J Exp Med 160:1485

Franssen JD, Urbain J (1985) Some facts and thoughts about internal images. Int Rev Immunol (to be published)

Horodniceanu F, Crainic R, Barme M (1980) Cell substrate and risk in killed poliomyelitis vaccine. Dev Biol Stand 47:35

Jerne NK (1974) Towards a network theory of the immune system. Ann Immunol (Paris) 125C:373

Jerne NK (1976) The immune system: a web of V domains. Harvey Lect 70:93

Jerne NK (1981) In: Westen-Schnurr I (ed) Idiotypes-antigens on the inside. Editiones Roche, Basel, pp 12

Jerne NK (1984) Idiotypic networks and other preconceived ideas. Immunol Rev 79:5

Jerne NK, Roland J, Caznave PA (1982) Recurrent idiotopes and internal images. EMBO J 1:243

Ju ST, Benacerraf B, Dorf ME (1978) Idiotypic analysis of antibodies to poly (Glu 60 Ala 30 Tyr 10). Interstrain and interspecies idiotypic crossreactions. Proc Natl Acad Sci USA 75:6192

Ju ST, Cramer DV, Dorf ME (1979) Idiotypic analysis of anti-GAT antibodies V. Distribution of an interspecies cross-reactive idiotype. J Immunol 123:877

Kauffmann RS, Noseworthy JH, Nepom JT, Finberg R, Fields BN, Greene MI (1983) Syngeneic monoclonal anti-idiotypic antibody identifies the cell surface receptor for reovirus. J Immunol $131: 2539$

Kennedy RC, Dreesman GR (1983) Common idiotypic determinant associated with human antibodies to hepatitis B surface antigen. J Immunol 130:385

Kennedy RC, Dreesman GR (1984) Enhancement of the immune response to hepatitis B surface antigen. In vivo administration of antiidiotype induces anti-HBs that expresses a similar idiotype. J Exp Med 159:655

Kennedy RC, Sanchez Y, Ionescu-Matiu I, Melnick JL, Dreesman GR (1982) A common human anti-hepatitis B surface antigen idiotype is associated with the group A confirmation-dependent antigenic determinant. Virology 122:219

Kennedy RC, Dreesman GR, Sparrow JT, Culwell AR, Sanchez Y, Ionescu-Matiu I, Hollinger FB, Melnick JL (1983a) Inhibition of a common human anti-hepatitis B surface antigen idiotype by a cyclic synthetic peptide. J Virol 46:653

Kennedy RC, Ionescu-Matiu I, Sanchez Y, Dreesman GR (1983b) Detection of interspecies idiotypic cross-reactions associated with antibodies to hepatitis B surface antigen. Eur J Immunol 13:232

Leo O, Slaoui M, Marvel J, Milner ECB, Hiernaux J, Moser M, Capra JD, Urbain J (1984) Idiotypic analysis of polyclonal and monoclonal anti-p-A 20 phenylarsonate antibodies of BALB/c mice expressing the major crossreactive idiotype of the A/J strain. J Immunol 134:1734 
Lindemann J (1973) Speculation on idiotypes and homobodies. Ann Immunol (Paris) 124C:171

Lindemann J (1978) Homobodies: do they exist? Ann Immunol (Paris) 130C:311

Lucas A, Henry C (1982) Expression of the major crossreactive idiotype in a primary anti-azobenzearsonate response. J Immunol 128:802

Meek K, Jeske D, Slaoui M, Leo O, Urbain J, Capra JD (1984) Complete amino acid sequence of heavy chain variable regions derived from two monoclonal anti-p-azophenylarsonate antibodies of $\mathrm{BALB} / \mathrm{c}$ mice expressing the major cross-reactive idiotype of the $\mathrm{A} / \mathrm{J}$ strain. J Exp Med $160: 1070$

Minor PD, Schild GC, Bootman J, Evans PMA, Fergusson M, Reeve P, Spitz M, Stanway G, Cann AJ, Hauptmann R, Clarke LD, Mountford RC, Almond JW (1983) Location and primary structure of a major antigenic site for poliovirus neutralization. Nature 301:674

Morein B, Sundquist B, Höglund S, Dalsgaard K, Osterhaus A (1984) Iscom, a novel structure for antigenic presentation of membrane proteins from enveloped viruses. Nature 308:457

Moser M, Leo O, Hiernaux J, Urbain J (1983) Idiotypic manipulation in mice: BALB/c mice can express the crossreactive idiotype of A/J mice. Proc Natl Acad Sci USA 80:4474

Nisonoff A, Lamoyi E (1981) Implications of the presence of an internal image of the antigen in anti-idiotypic antibodies: possible application to vaccine production. Clin Immunol Immunopathol $21: 397$

Norrby E (1983) Viral Vaccines: the use of currently available products and future developments. Arch Virol 76:163

Noseworthy JH, Fields BN, Dichter MS, Sobotka C, Pizer E, Perry LL, Nepom JT, Greene MI (1983) Cell receptors for the mammalian reovirus. I. Syngeneic monoclonal anti-idiotypic antibody identifies the cell surface receptor for reoviruses. J Immunol 131:2533

Osterhaus ADME, UytdeHaag FGCM (1985) Lymphocyte hybridomas: production and use of monoclonal antibodies. In: Spier R, Grissfiths B (eds) Animal cell biotechnology. Academic, New York (to be published) Proceedings of the workshop on abnormal cells, new products and risks (1984)

Osterhaus ADME, van Wezel AL, van de Marel P, van Steenis G (1981 a) Production of monoclonal antibodies against poliomyelitis and rabies viruses. In: Peeters H (eds) Prot of the Biol F1. Proceedings of the twenty-ninth colloqium, vol 29, p 743, Pergamon Press, New York

Osterhaus ADME, Van Wezel AL, Van Steenis B, Drost GA, Hazendonk TG (1981 b) Monoclonal antibodies to polioviruses: production of specific monoclonal antibodies to the sabin vaccine strains. Intervirology $60: 218$

Osterhaus ADME, Van Wezel AL, Hazendonk TG, UytdeHaag FGCM, Van Asten JAAM, Van Steenis B (1983) Monoclonal antibodies to polioviruses. Comparison of intratypic strain differentiation of poliovirus type I using monoclonal antibodies versus cross-absorbed antisera. Intervirology $20: 129$

Osterhaus A, Weijer K, UytdeHaag F, Jarrett O, Sundquist B, Morein B (1985) Induction of protective immune response in cats by vaccination with feline leukemia virus iscoms. J Immunol 135:1

Rajewski K, Takemori T (1983) Genetics, expression, and function of idiotypes. Annu Rev immunol $1: 569$

Reagan KJ, Wunner WH, Wiktor TJ, Koprowski H (1983) Anti-idiotypic antibodies induce neutralizing antibodies to rabies virus glycoprotein. J Virol 48,3:660

Roux KH, Metzger DW, Kazdin DS, Horng WJ (1984) Induced latent allotypes within rabbit anti-cross-reactive idiotype reagents. Direct immunoelectron microscopic evidence. Eur J Immunol $14: 910$

Sacks DL, Sher A (1983) Evidence that anti-idiotype induced immunity to experimental african trypanosomiasis is genetically restricted and requires recognition of combining site-related idiotopes. J Immunol 131,3:1511

Sacks DL, Esser KM, Sher A (1981) Immunization of mice against African trypanosomiasis using anti-idiotypic antibodies. J Exp Med 155:1108

Sacks DL, Kelsoe GH, Sachs DH (1983) Induction of immune responses with anti-idiotypic antibodies: implications for the induction of protective immunity. Springer Semin Immunopathol $6: 79$

Sharpe AH, Gaulton GN, McDade KK, Fields BN, Greene MI (1984) Syngeneic monoclonal antiidiotype can induce cellular immunity to reovirus. J Exp Med 160:1195

Sinal NH (1982) Regulation of azophenylarsonate-specific repertoire expression. J Exp Med 156:1352 
Sommé G, Roth C, Bismuth G, Leclercq L, Mazié JC, Théze J (1984) Public idiotypes and/or internal images in the anti-poly $\left(\mathrm{Glu}^{60} \mathrm{Ala}^{30} \mathrm{Tyr}^{10}\right)$ response: analysis by monoclonal antibodies. Ann Immunol (Paris) 135C:57

Strosberg AD (1983) Anti-idiotype and anti-hormone receptor antibodies. Springer Semin Immunopathol $6: 67$

Theze J, Moreau JL (1978) Genetic control of the immune response to GAT terpolymer I. Intrastrain and interspecies crossreactive idiotype. Ann Immunol (Paris) 129C:721

Urbain J, Wikler M, Franssen JD, Collignon C (1977) Idiotypic regulation of the immune system by the induction of antibodies against antiidiotypic antibodies. Proc Natl Acad Sci USA 74:5126

UytdeHaag FGCM, Osterhaus ADME (1985) Induction of neutralizing antiboy in mice against poliovirus type II with monoclonal antiidiotypic antibody. J Immunol 134:1225

UytdeHaag FGCM, Loggen HG, Logtenberg T, Lichtveld RA, Van Steenis B, Osterhaus ADME (1985a) Human peripheral blood lymphocytes from recently vaccinated individuals produce both homotypic and heterotypic neutralizing antibody upon in vitro stimulation with one type of poliovirus. J Immunol (to be published)

UytdeHaag F, Bunschoten H, Osterhaus A (1985b) Igh-V ${ }^{a}$ linked expression of a major cross reactive idiotope associated with reactivity against rabiesvirus glycoprotein: analysis by syngeneic monoclonal anti-idiotypic antibody. (to be published)

von Seefried A, Chun JH (1980) Serially subcultivated cells as substrates for poliovirus production for vaccine. Dev Biol Stand 47:25

Zoler ML (1984) Anti-idiotypic antibodies : a safer way to immunize against AIDS?. Biotechn 110:923 